\title{
nature
}

\section{Biomedical boom, forget the rest?}

As the US budget looms, the repercussions that President Bush's campaign promises will have on research and on other government programmes are becoming all too clear. Researchers face a tough struggle in lobbying Congress.

$\mathrm{G}$ eorge W. Bush, the new president of the United States, is clearly determined to present himself as a man who means what he says. It should come as no surprise, then, that the hurriedly prepared 2002 budget that he is obliged by law to propose to Congress before the end of February will be shaped almost entirely by the direct pledges made during his election campaign. These included a promise to continue with plans to double the budget of the National Institutes of Health (NIH) over a five-year period, to boost investment in education, to balance the budget and to have enough left over to give Americans a significant cut in income tax.

Bush is likely to announce a $\$ 3$ billion increase in funding for the NIH up front, instead of leaving it to Congress, as his predecessors have done, to come up with extra money for its favourite research agency. This honest and straightforward move might be expected to thrill the scientific community, but it raises problems. The White House, unlike Congress, tends to consider the research budget as a whole in drawing up spending plans: NIH's hefty increase will leave almost nothing for other research agencies. The result will be a grotesque imbalance between spending in biomedical research and that in other disciplines of science. Rectifying this will now fall to Congress, where support for non-health research has traditionally been weakest.

Meanwhile, Bush, in order to assure the credibility of his tax-cut plan, will have to propose budget cuts in other government programmes - including social welfare programmes - to permit NIH's expansion. The danger is that the closure of nursery schools and homeless shelters to pay for more grandiose academic medical centres might fracture the bipartisan consensus that has driven the NIH expansion in Congress.
Even so, the $\$ 3$ billion increase at NIH is expected to stick, at least this year, leaving the rest of American science behind in the dust. The National Science Foundation, for example, may find its budget frozen, despite all the fine words about its role in underpinning scientific progress for every application, including health and defence.

The situation at the Department of Energy, which supports most US physics and runs many of the nation's large scientific facilities, is even bleaker. In the land of opportunity for all, physics budgets that have been flat for several years spell a dangerous stagnation for US physics. Since the last Bush left office, practically no major new facilities have been planned, built or even seriously contemplated.

Physical scientists' response to their predicament thus far has been to consider a new lobby shop in Washington that might emulate the recent successes of their biomedical brethren through groups such as Research!America. If the precedent of the Reagan administration is any guide, Washington will soon enjoy an influx of such lobbyists, representing every interest in the land that feels threatened by Bush's effort to control public spending.

But science needs to send a more sophisticated message than the railroad operator, the sugar-cane grower, the banana importer or the small restaurateur. A more intelligent response by the community would be to start facing facts, and to offer to help the administration set scientific priorities. That will require strengthening the science office in the White House to coordinate research policy and, in effect, prevent the sort of imbalance that will crop up in next week's budget proposals.

Bush will appoint his science team later this spring. They will soon learn whether the community is united behind such an approach or bitterly divided between the haves and the have-nots.

\section{Europe's infrastructure failure}

\section{Despite expectations to the contrary, the European Commission has failed to back research facilities for the long term.}

E uropean proponents of the much-heralded post-genomics revolution are suffering the curse of Sisyphus. They seem condemned for ever to gain support for European-level research infrastructures - and then to watch as politicians tip the plans, like Sisyphus's boulder, back to the bottom of the hill.

Two facilities, the European Mouse Mutant Archive and the European Bioinformatics Institute, are about to witness this perverse manoeuvre yet again. Everyone - politicians, bureaucrats and scientists - acknowledges the fundamental importance of these facilities, created with the help of the commission's fourth Framework programme of research (FP4). Yet a sustained commitment to keep them going - let alone to help them keep pace with genomics - has failed to materialize. After appearing to be convinced, the commission has backed down at crucial moments.

Consider the 1999 launch of FP5, which unexpectedly declared that "routine" services could not be funded (see Nature 402, 4; 1999). This was a response to the political aversion of European Union member states to giving long-term support for service facilities. No other organization came to the rescue. Widespread outrage forced the commission last year to reallocate a small part of Framework money for the infrastructures using a new — and temporary — definition of "routine". This money has just started to be allocated (see page 967).

Since his appointment in 1999, research commissioner Philippe Busquin has been sympathetic to the problem of infrastructures. And he has shown true scientific vision, appearing to embrace a desire for a rational exploitation of the human genome sequence in Europe. The implications were that the research infrastructures needed for this would be resolved in FP6, due to be launched next year.

It now seems that FP6 will not deliver the goods after all. A draft of the commission's first proposal for the programme indicates that the basis for commission support will remain essentially unchanged: no funds for routine upkeep of established facilities, even though total money for infrastructures will increase.

Member states can change this if they want, but national interests tend to dominate their thinking, and a unanimous voice is unlikely to be heard. And researchers? Like Sisyphus, yet again. 